\title{
The Psychology of Harmony and Harmonization: Advancing the Perspectives for the Psychology of Sustainability and Sustainable Development
}

\author{
Annamaria Di Fabio ${ }^{1, *}$ and Akira Tsuda ${ }^{2}$ \\ 1 Department of Education and Psychology, University of Florence, 50135 Florence, Italy \\ 2 Department of Psychology, Kurume University, Kurume 839-8502, Japan; tsuda_akira@kurume-u.ac.jp \\ * Correspondence: adifabio@psico.unifi.it
}

Received: 29 August 2018; Accepted: 6 December 2018; Published: 11 December 2018

\begin{abstract}
After delineating the roots of harmony in the literature from both the Eastern and the Western perspectives, the paper introduces the new Psychology of harmony in terms of harmonization that widens the perspective calling for psychological contributions regarding components, processes and building strengths in a preventive perspective. The complex construction of Harmony from a psychological perspective underlines the concept of relationality. Harmony results at three main points, with oneself, with others, and with nature/the natural world, also taking into account the spatial and temporal perspectives. The Psychology of harmony as harmonization represents a pillar for a new research area in the psychology of sustainability and sustainable development, considering harmonization in geographical and temporal perspectives, including meaningful construction processes from the past, to the present, and into the future using reflexivity processes at the individual, group, community, social, and national levels. Introducing the innovative psychology of harmony as harmonization the present article offers promising perspectives for research and intervention with the aim to individuate and foster new strengths from a preventive perspective.
\end{abstract}

Keywords: psychology of harmony; harmonization; balancing; psychology of sustainability and sustainable development; relationality; prevention; primary prevention; cross cultural primary prevention

\section{Following the Roots of Harmony in the Literature: Psychological Lens toward Harmonization}

The Psychology of harmony as harmonization represents a new pillar in the psychology of sustainability and sustainable development, considering harmonization in geographical and temporal perspectives, including meaningful construction processes from the past, to the present, and into the future using reflexivity processes at the individual, group, community, social, and national levels. Introducing the innovative psychology of harmony as harmonization the present article offers promising perspectives for research and intervention with the aim to individuate and foster new strengths in a preventive perspective. In order to do this, the article moves from the roots of harmony in the literature. After that the present offers (a) the elaboration of the concept of harmony, by distinguishing different facets of the concept; (b) the proposal that the development of particular psychological strengths will foster processes of harmonization in the different distinguished domains; and (c) the claim that fostering processes of harmonization will aid sustainability.

From ancient times the concept of harmony has been widely studied in both Eastern and Western philosophical literature. In Western philosophy, the origin of the concept of harmony can be traced back to Pythagoras (575 BC-490 BC) who discovered harmonic progression in music and its analogy with the movement of the celestial bodies. For Pythagoras order and harmony are recognized in numbers. At the basis of classical Greek art, as well as medical theory, balance was integral. Disease is considered an 
imbalance between the environment and the body, and within the body, among the humours. The care for disease consists in restoring harmony. So, in general, balance integrates the idea of harmonic symmetry and of proportionality between different parts. In these terms Heraclitus ( 535 BC- 475 BC) introduced a definition of harmony as a unification of diversity through the concordance of discordant elements. Guthrie [1], a scholar of Greek philosophy, commenting on Heraclitus's thought underlines that everything is created of opposites and all things are subject to internal tension; tension is the creative force of harmony. If Pythagoras highlights harmony as numerical order, Heraclitus emphasizes that there can be no harmony without tension and opposites.

Starting from Pythagoras, Plato (428 BC-348/347 BC) refers to an order of the cosmos based on the numbers that guarantee harmony. Furthermore Plato individuated three classes of people in the state (first class which includes farmers, artisans, merchants; second class that of custodians who defend the city; third class which consists of governors) and the three elements of the soul (desiring/concupiscent part; irascible/volitional part; rational part). Plato individuated three virtues (temperance, courage, wisdom) and each of them corresponds to a class of people and the respective element of the soul. The three virtues are: Temperance, as the moderation of desires which, if excessive, result in unruliness; courage or strength of mind necessary to implement virtuous behaviors; and wisdom (as a control of passion), which constitutes the basis of all other virtues. Harmony among these classes, the elements, and the relative virtues refers to the virtue of justice. This virtue realizes the harmonious equilibrium and the balance of all the other virtues present in the virtuous man and in the perfect state. In the Middle Ages, Tommaso D'Aquino (1225-1274) underlined that the term harmony refers to the sounds in music, but it could be extended also to every proportion of the parties, in particular with respect to harmony of the elements in the body until the universal order that derives from God. The concept of harmony in the modern Western philosophy developed with a focus on rationalism and was associated with the efforts to rebuild unity in man and between man and the world. Leibniz (1646-1716) refers to the concept of pre-established harmony. The body is a complex of immaterial substances called "monads" organized under a dominant monad, the soul, which gives them unity and constitutes the centre. Harmony is what should be reached between the different monads. In the modern Western science the fractal theory [2] tried to describe the harmonic complexity of the real world. A fractal is a geometric object that repeats in its shape in the same way on different scales, and therefore enlarges any part of it obtaining a figure similar to the original. They are coined to describe some mathematical behaviors that seem to have a chaotic behavior. Fractals permit the understanding of dynamic systems using mathematical algorithms and equations and thus offering a key to better understand reality.

In Eastern philosophy and thought the definition of harmony has deep roots, as it develops and continues to flourish at its best. Generally in Eastern culture the concept of harmony is central to the teachings of Confucius [3-6]. In fact the world "he" (harmony) is one of the most recurrent characters in Mencius [6]. If in the Tao Te Ching (The book of the Ways and its Virtue), an ancient Chinese philosopher (605 BC-531 BC) highlighted the importance of living in harmony with nature to realize equilibrium and internal peace of mind [3], the Confucian classics underlined harmony as a principle of reference for interpersonal relationships and social roles, fundamental to the solidity of families and prosperity of society [3]. The importance to harmonize with others by goodness without senselessly following others was underlined [4]. Confucianism refers also to a "grand harmony," considering that the world includes many different things that can be harmonized even if they are in constant change and highlighting the confidence in an ultimate harmony among the things in the world [4].

Confucianism individuates five virtues (human excellence, rightness, ritualized propriety, wisdom, sageliness) and affirms that it is not only the practice of the virtues, but the practice of the virtues in harmony, that produces the highest virtue. The practice of all the five virtues permits the attainment of superior virtue of Heavenly Virtue [5]. Furthermore Confucianism underlines a concept of harmony that highlights the dynamic nature of tension and diversity within harmony, whereas Moist highlights the element of accord in harmony as a form of harmony and unity among themselves [5]. Moist is suspicion about differences and supports sameness whereas Confucianism tries to integrate differences 
rather than accept sameness. The moist notion of harmony underlines that sameness or similarity among individuals brings unity in the world, whereas the Confucian notion of harmony emphasizes plurality and diversity. Daoism also underlines the importance of the existence of pairs of opposites. The two attributes of the pairs are not only in contrast but also in generative tension, and this creates harmony considering mutually completing and mutually compensating relationship [5].

Considering this wealth of reflections, the concept of harmony in Eastern countries can be understood through the analysis of Chinese classical texts defining the principal attributes of harmony [7]: Harmony is an emergent order; it is not uniformity; it is a holistic perception; it is a dynamic equilibrium. First of all, harmony is an emergent order. The references are to cooking and music that are not unchanging and pre-given states. Harmony exists in a reality that is to be shaped every time. Harmony is not uniformity since one aspires to harmony and not sameness [8]. Furthermore, individuals can establish harmonious relationships with the world without losing their individuality [9], each individual is part of the whole, and not excluded. This is the difference between harmony and sameness [9]. Harmony is a holistic perception, a global sense of things rather than a focus on a specific thing [9]. Moreover, with regard to this aspect, it is possible to differentiate between harmony and uniformity [7]: Uniformity regards a univocal system, a total that has not any parts or a one-sided association that incorporates the parts under a total; harmony instead is a multifaceted system of many elements, which brings an emergent order of the whole. Finally, harmony is a dynamic equilibrium. It is different from the traditional definition of equilibrium that refers to a post-perturbation state whereas dynamic equilibrium is constantly maintained "to have the emotions welling up and yet in due proportion is also a state of the mean [equilibrium]" [10].

The Eastern perspective considers harmony as a comprehensive process not conforming to any pre-set order, most properly called harmonization $[4,5]$. Harmony is thus a process, not a state, a dynamic process of harmonization that calls for being tuned with the world, from the inner self toward the outward [11].

\section{Psychology of Harmonization}

In the Western and Eastern reflections harmony shows fundamentally the following main difference (see Table 1): Western philosophical thought considers harmony as based on a pre-set order for a linear progressive model, whereas Eastern thought as based on a generated rather than pre-given order and refers to generative creativity for a comprehensive process of harmonization. On the other hand, looking for similarities, in both Western and Eastern lines of thoughts the deep meaning of harmony is considered as a process and not a state. Harmony expresses itself as a dynamic process whether it is complying with the perfect order in a Western perspective, or from an Eastern perspective, if this order is not pre-determined but generated through harmonization. So, we can affirm that harmony always asks for harmonization [11]. Harmony is deeply understood only in terms of the process. It does not merely entail mixing different elements, but is relative to the balancing of different elements into an organic whole (Yan Ying, 4th century BC). Harmonization is thus a process based on balancing [11,12].

Table 1. The concept of harmony: Differences and similarities Western and Eastern philosophy.

\begin{tabular}{lll}
\hline & \multicolumn{1}{c}{ Western Philosophy } & \multicolumn{1}{c}{ Eastern Philosophy } \\
\hline Differences & $\begin{array}{l}\text { Harmony: Based on a pre-set } \\
\text { order for a linear progressive } \\
\text { model }\end{array}$ & $\begin{array}{l}\text { Harmony: Generated order; } \\
\text { generative creativity as a } \\
\text { comprehensive process }\end{array}$ \\
\hline Similarities & Harmony is: & A process and not a state; \\
& $-\quad$ & $\begin{array}{l}\text { A dynamic process generated through harmonization and based } \\
\text { on balancing different elements into an organic whole. }\end{array}$
\end{tabular}


Harmony includes various levels [4]: Within the individual, between the individuals, between human beings and the natural world/universe (see Table 2).

Within the individual, harmony refers to the person and the process of harmonizing various parts of the body, mind-heart, and different purposes in life in a well-functioning organic whole.

Between individuals, harmony focuses on individual/individuals, as harmony can be realized between individuals at different levels: Family, community, nation, and the world. At this level, harmony can be realized inside the society and also with other societies, within a society with different ethnic groups (or political parties), within the same ethic group with different kin, and among the same kin.

Harmony between human beings and the natural world/universe refers to a special relationship including the harmony of human societies and the natural world with the ultimate goal of reaching grand harmony throughout the cosmos. In this regard two main shades between the Daoist and the Confucian notions of harmony can be found. For Daoism harmony is primarily between humanity and the natural world, whereas for Confucianism harmony is more active in taking initiatives to generate harmony within society, even though harmonizing the world is also part of Confucian thought. In Daoism harmony is accommodating the natural world that has a propensity to harmonize in itself, whereas in Confucianism the emphasis is on the necessity to act toward harmonization also transforming society and the world. So, we could say that a difference between Daoism and Confucianism is that Daoism aspires to harmonize the world whereas Confucianism aims to harmonize with the world [4].

Table 2. Various levels of harmonization in the classic current Eastern perspective.

\begin{tabular}{|c|c|c|c|}
\hline Within the Individual & Between the Individuals & \multicolumn{2}{|c|}{ Between Human Beings and the Natural World/Universe } \\
\hline \multirow{3}{*}{$\begin{array}{l}\text { Referring to person and } \\
\text { process to harmonize various } \\
\text { parts of body, mind-heart, } \\
\text { different purposes in life in a } \\
\text { well-functioning organic } \\
\text { whole }\end{array}$} & $\begin{array}{l}\text { Referring to } \\
\text { individual/individuals: Family, } \\
\text { community, nation, world, inside } \\
\text { the society and also with other } \\
\text { societies, within a society with } \\
\text { different ethnic groups (or }\end{array}$ & \multicolumn{2}{|c|}{$\begin{array}{l}\text { Referring to human societies and the natural world with the } \\
\text { ultimate goal to reach the grand harmony throughout the } \\
\text { cosmos }\end{array}$} \\
\hline & & Daoism: & Confucianism: \\
\hline & & $\begin{array}{l}\text { - } \\
\text { harmony is between } \\
\text { natural world; } \\
\text { Harmony is } \\
\text { accommodating the } \\
\text { natural world that have } \\
\text { a propensity to } \\
\text { harmonize in itself; } \\
\text { Aim to harmony } \\
\text { the world. }\end{array}$ & 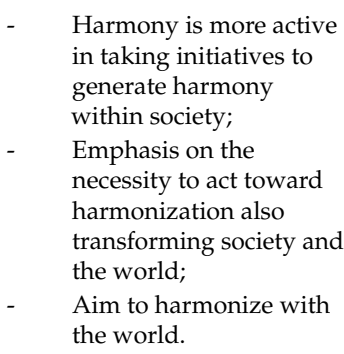 \\
\hline
\end{tabular}

Adapted from References [4,5].

Deepening the reflection generated from the philosophical perspective to encompass the psychological perspective, psychological components and processes are important to be taken into consideration, to facilitate to be able to realize harmonization, to facilitate "being together harmoniously". In particular the present reflection tries to integrate different psychological contributions as the Guichard's concept of SIF and the relational theory of working by Blustein, considering the importance of inner relationality and relationality with others, until the relationality with natural world.

Launching an integrated psychological point of view [11,12] if harmony is naturally relational [5], a first important psychological deepening calls for psychologically widening the concept of relationality (see Table 3). First of all, relationality asks for an inner relationality [13], constructing positive 
relationship with the parts of self [14-16]; with others in terms of person, group, community/ies [17,18] and with relational contexts, considering not only external relational contexts but also internal relational contexts [19]; with nature (world) [11,12].

At the basis of relationality towards others psychologically, there is the positive and balanced relationality with part of oneself $[12,20,21]$. Considering the construction of identity, people are plural beings with a dynamic system of plural individual identities [22]. They unify themselves starting from their own personal experiences by constructing expectations for their future [23]. Each person interacts in different contexts, obtaining different experiences that contribute to different self-images called Subjective Identity Forms (SIF, [15]), based on the different roles carried out in different environments. Individual identity is multiple and dynamic within a Subjective Identity Forms System (SIFS) where some Subjective Identity Forms (SIFs) are more relevant than others emerging in terms of aspired SIFs. The aspired SIFs stimulate individuals to imagine their own future, giving priority to those perspectives that give consistency to all the SIFs of a person. A harmonic construction in this system asks for balancing through a positive relationality among different Subjective Identity Forms to realize the harmony of the whole self. It is essential for building authenticity and positive self-attunement [17] as the basis of personal/social meaning and positive energy for learning, designing and flourishing one's own life.

Another precious contribution of an in-depth study of inner relationality [14] concerns the existence not only of external relational contexts but also of internal relational contexts [19]. People experience different relational contexts that are connected to each other. It is important to understand how people make meaning of their interactions with others and with the broader social world in different contexts on the one hand, and on the other hand how relational influences, both historic and contemporary, are internalized, with implications for the ways in which individuals experience aspirations, interests, motivation and values [24]. Interpersonal relationships, as well as internalized relational contexts play fundamental roles in the development of the person and this positive relationality is at the basis of a worthwhile and meaningful life. It is also essential that external and internal contexts are balanced for the individual to reach the whole inner harmony $[11,21]$.

Relationality is thus of the person with oneself, with different parts of the self, with her/his internal relational contexts and external context in relation with others, considering different levels of interactions (dyadic interactions, triadic interactions, group interactions), different levels in the relationship between people (peer, hierarchical), and different contexts (family, school, work, community.

Finally, relationality is also with the natural world, not only between human beings and the natural world/universe, but also starting from the perspective of the relationships each person is able to harmonically build with the natural / world/universe.

On these bases, harmony results in three main domains, with oneself, with others, and with nature/the natural world, considering complexity and balancing as the key ingredients, and also taking into account both the geographical and temporal dimensions [11,21]. The innovative framework of the psychology of harmony as harmonization, using psychological lens, is able to present a promising perspective for research and intervention, offering new opportunities for building strengths and preparing solutions in a preventive perspective in relation to the main issues of the Sustainability Science.

For each of these domains, the psychology of harmonization aims to contribute to research and intervention for recognizing, constructing and fostering strengths for the harmonization process in a positive preventive perspective framework [11,21].

Harmonization with oneself puts in place some psychological considerations: We are the instrument to play our music and we are to be "harmoniously harmonized" to play at our best, if we use the metaphor of music $[11,21]$. The importance emerges for the person to be tuned, as one would an instrument, and to be ready, active, and proactive in this process of generative tuning not on 
the basis of a pre-established order, but flexible and ready for new balanced constructions in playing our music.

Table 3. Psychology of harmonization: Launching an integrated psychological point of view.

\begin{tabular}{|c|c|c|c|c|}
\hline \multicolumn{3}{|c|}{ Relationality $[13,20]$} & \multirow[t]{2}{*}{ Harmony [11] } & \multirow[t]{2}{*}{ Harmonic Harmonization [11] } \\
\hline Type & Description & Levels & & \\
\hline inner & $\begin{array}{l}\text { inner positive } \\
\text { relationality: } \\
\text { Relationship with the } \\
\text { parts of self }[15,16,20] \\
\end{array}$ & $\begin{array}{l}\text { different parts of self; } \\
\text { plural identities }\end{array}$ & with oneself & \multirow{4}{*}{$\begin{array}{l}\text { Processes for balancing both intrapersonal and } \\
\text { interpersonal harmony, and in-with } \\
\text { person/individuals and the natural world. } \\
\text { Balancing the harmonic re-composition of } \\
\text { intrapersonal and interpersonal complexity } \\
\text { included the natural world both synchronically } \\
\text { and diachronically. } \\
\text { Harmonization: relationality with oneself, the } \\
\text { others and contexts included the natural world } \\
\text { both geographically: Next and far (wide } \\
\text { synchronicity) } \\
\text { and temporally: From the past and the roots, to the } \\
\text { present, to the future (wide diachronicity). } \\
\text { Harmonization geographically and temporally } \\
\text { based regards individual, group/s, } \\
\text { community/ies, including a new community (from } \\
\text { global to universal) mainly with also the natural } \\
\text { world [11]. }\end{array}$} \\
\hline others & $\begin{array}{l}\text { person, group, } \\
\text { community/ies }[17,18]\end{array}$ & $\begin{array}{l}\text { different levels of } \\
\text { interactions (dyadic } \\
\text { interactions, triadic } \\
\text { interactions, group } \\
\text { interactions) }\end{array}$ & with others & \\
\hline $\begin{array}{c}\text { relational } \\
\text { contexts }\end{array}$ & $\begin{array}{l}\text { external relational } \\
\text { contexts + internal } \\
\text { relational contexts [19] }\end{array}$ & $\begin{array}{l}\text { different levels in the } \\
\text { relationship between } \\
\text { people (peer, hierarchical) } \\
\text { different contexts (family, } \\
\text { school, work, } \\
\text { community/ies) }\end{array}$ & $\begin{array}{l}\text { with external and } \\
\text { internal relational } \\
\text { contexts }\end{array}$ & \\
\hline nature & $\begin{array}{l}\text { Personally, with } \\
\text { nature/the natural } \\
\text { world }[11,21]\end{array}$ & $\begin{array}{l}\text { relationships each person } \\
\text { is able to harmonically } \\
\text { build with the natural } \\
\text { /world/universe. }\end{array}$ & $\begin{array}{l}\text { with nature/the } \\
\text { natural world }\end{array}$ & \\
\hline
\end{tabular}

These strengths can be invigorated at an individual level, not only in terms of adaptive remediating answers, as coping or resilience for example, but in terms of energizing and generative strengths, increasable through specific training, such as Intrapreneurial Self-Capital [25] in a positive preventive framework [26,27]. Intrapreneurial Self-Capital [ISC, 25] is a core of individual intrapreneurial resources "to deal with the frequent changes and transitions by creating innovative solutions when confronted with constraints of the environment to turn constraint into resources" (p. 99). It is a higher order construct that includes seven sub-constructs: Core self-evaluation in terms of positive self-concept [28]; hardiness, in terms of resistance, composed of three dimensions commitment, control, challenge [29]; creative self-efficacy, the individual perception of being able to face and solve problems creatively [30]; resilience as the perceived ability to cope with hardship [31]; goal mastery as the perceived ability to pursue the development of one's own skills [32]; decisiveness as the perceived ability to make decisions timely in different contexts [33]; vigilance in terms of adaptive and careful searching for relevant and consistent information [34]. ISC fosters a perspective focused on adapting in difficult situations, introducing new possibilities for balancing and transforming constraints into resources in a proactive preventive manner.

Another strength at an individual level that can be developed and takes into account the balancing between intrapersonal and interpersonal aspects is positive relational management [13]. This construct includes the concepts of respect and caring for the self and the others and the relationships/connectedness between people $[13,19,35]$. It underlines the value of balancing the self in relationships attaining harmonic conditions. Positive relational management encompasses three dimensions: Respect (my respect for others, the respect of others for me, my respect for myself), caring (my care for others, the care of others for me, my care for myself), and connectedness (my connectedness with family members, with friends, with significant others, and reciprocity). Positive relational management facilitates harmony considering the relevance of respect, caring and relationality/connectedness toward oneself and others in relationships across different contexts [13].

Regarding the strengths that can be invigorated for the relationships with others, we have resources that can be enhanced in terms of workplace relational civility [27] and its specific application in an academic context in terms of academic relational civility [14,36]. Workplace Relational Civility [37] is defined as a relational style "characterized [sic] by respect and concern for oneself and others, interpersonal sensitivity, personal education, and kindness toward others. It includes civil behaviours [sic] such as treating others with dignity and respecting social norms to facilitate peaceful and productive cohabitation" [37]. Workplace relational civility includes the following three dimensions: 
Relational decency at work, in terms of relationships based on decency and characterized by respect for the self and others, being able to express beliefs and opinions freely, assertiveness, being tactful; Relational culture at work, in terms of courtesy, kindness, politeness; Relational readiness at work, in terms of speed in understanding the feelings of others and exhibiting proactive sensibility, ability to understand the emotions of others, delicacy, empathy, and compassion. Academic relational civility presents the same dimensions but with respect to the organizational specific academic context $[14,36]$. Workplace relational civility implies a scale with a mirror modality of evaluation (me with others, part $\mathrm{A}$, and others with me, part B) allowing an in-depth evaluation of interpersonal interactions considering one's own contribution and the contribution of others in relationships. Workplace relational civility represents an incremental strength permitting individuals also to reflect on their own relational behaviors and to examine the responses of others, promoting a harmonization of intrapersonal and interpersonal components to enhance positive, adaptive, flourishing and harmonic relationships.

Another example of resources for harmonization with others in the work context that can be enhanced is the innovative construct of leadership in terms of Human Capital Sustainability Leadership [37]. The new Human Capital Sustainability Leadership [37] is a style of management that can permit the realization of harmony for individuals and organizations balancing different intrapersonal, interpersonal and organizational aspects for creating flourishing environments improving a virtuous circle for the wellbeing of individuals and healthy organizations [26,38-42]. The Human Capital Sustainability Leadership is a higher order construct composed of four specific types of leadership (ethical, sustainable, mindful and servant leadership). Leadership is evaluated from the point of view of the leaders. Ethical leadership aspires to fair aims and to the empowerment of the organization members [43]. Sustainable leadership creates sustainable learning conditions, develops rather than exhausts human resources, supports collaborators in their personal/career growth, and is focused on the crucial aspects of work ignoring superfluous aspects [44,45]. Mindful leadership regards putting on the shoes of collaborators, anticipating the request of collaborators, being aware of the strengths and the limitations of collaborators, recognizing the importance to control personal emotions, particularly under stress [46,47]. Servant leadership aims to identify the needs of collaborators and assist them in considering their moral responsibility $[48,49]$. This new construct of human capital sustainability leadership as a single second-order factor aims to promote employee wellbeing calling for a new style of leadership in human resource management for building harmonization processes in the organization.

Regarding the aspect of harmonization with nature/the natural world, on the basis of current research [50,51] empathy is recognized as an individual preventive strength. Empathy in terms of the reactions of one individual to the observed experiences of another [52] considers four different dimensions: Fantasy, tendencies to transpose themselves imaginatively into the feelings and actions of fictitious characters in books, movies, and plays; Empathic concern, other-oriented feelings of sympathy and concern for unfortunate others; Perspective taking, the tendency to spontaneously adopt the psychological point of view of others; Personal comfort, self-oriented feelings of personal peacefulness and comfort in interpersonal settings. In the literature empathy has been associated with the construct of connectedness to nature [50,51]. Connectedness to nature was originally defined as "the extent to which an individual includes nature within his/her cognitive representation of self" [52], but has been extended to include the individual's affective and experiential connection with nature [53]. Individuals who have higher connectedness to nature are more predisposed to perceive themselves as part of a broader natural community. They perceive themselves as belonging to the natural world and that the world belongs to them, considering that their own wellbeing is related to the wellbeing of the natural world [53]. The contribution of empathy to connectedness to nature showed that individuals who perceive themselves as empathic with other people are also likely to express concern and connectedness to the natural world. Empathy seems to be a very interesting preventive variable in terms of its strengths for harmonization related to attitudes towards the natural 
world and interpersonal relationships with others, and in terms of its potential to be enhanced through specific training [54-56].

Another strength that can be considered both as a more general preventive asset to increase the flexibility required in the post-modern era and as a useful resource for harmonizing is the construct of the acceptance of change [57]. It is defined as the "tendency to embrace rather than shy away from change" [57]. Individuals who accept change consider that it could have a positive effect on their lives and that they have the possibility to learn from change. This construct has five dimensions: (1) Predisposition to change, the ability people have to learn from change and to employ change to enhance the quality of their lives; (2) support for change, perceived social support from other people when facing changes; (3) change seeking, propensity to search for change, ability to obtain and retain information, and to express a necessity for new stimuli; (4) positive reaction to change, perception of positive emotional reactions to change seen as positive and considering to have benefits from it; and (5) cognitive flexibility, mental ability to swing between different concepts adapting cognitive processing strategies [57]. Acceptance of change can be considered a resource to face adaptively the continuous changes of the 21st century in terms by offering strengths to find new balances within the person, with others and with different contexts, including the natural world.

These are only limited examples of psychological production in theory and application to reinforce the processes of harmonization for recognizing, building and fostering strengths. In a primary prevention perspective [27,58-61], building strengths for individuals and communities, for the realization of harmonization processes is an important psychological area that can benefit from the individual and the communities. At the same time, it requires attention to the construction of wellbeing for individuals, organizations and the natural world, with a focus on the adaptive principle of balancing [11,21].

The psychology of harmonization emerges as an important asset for sustaining processes for building and preserving or re-building a "harmonic harmony" [11,21]. It implies processes of balancing in front of complexity and opportunities, focusing on an open-mind perspective of the relational dimension as inner relationality, relationality in/with others both close and far in the space and in the time, relationality with the natural world. It attends to the intrapersonal dimension, starting with the construction of the relational interpersonal focus by balancing themselves and better balancing relationships with others and our relationships with the natural world. The psychology of harmonization aims to highlight the importance of research and interventions from this perspective of "harmonic harmonization" [11,21] founded on relational harmony, balancing both between intrapersonal harmonization and interpersonal harmonization and in/with a person and the natural world. This perspective widens the horizon balancing the harmonic re-composition of intrapersonal and interpersonal complexity included the natural world both synchronically and diachronically $[11,62]$. Harmonic harmonization refers to relationality with oneself, with others and with contexts and the natural world both geographically near and far (wide synchronicity) and temporally from the past and the roots, to the present, to the future (wide diachronicity) $[11,62]$. Harmonization geographically and temporally includes individual, group/s, community/ies, as well as a new community (from global to universal) mainly with the natural world [11].

\section{Psychology of Harmonization as a Pillar for Psychology of Sustainability and Sustainable Development}

The psychology of sustainability and sustainable development $[11,26]$ represent an innovative area of research in the field of psychology. It studies sustainability topics, considering the contributions that a psychological perspective can give to the trans-disciplinary science of sustainability and sustainable development. This new psychological perspective widens the concept of sustainability by adding to a perspective that exclusively considers the ecological and socio-economic environment [63] with the aim to respond to the enhancement of wellbeing and the quality of life of individuals [26]. The psychology of sustainability goes beyond the traditional perspective of the three "Es" (economy, 
equity, ecology) and the traditional definition of sustainability based on preventing damage in terms of abuse, exhaustion, and permanent modification. It presents a new positive perspective built on advancement in terms of enhancement, development, and flexible transformation [26]. Psychology of sustainability and sustainable development reflects on full sustainability for individuals, enhancing sustainable intrapersonal and interpersonal talents, considering reflexivity and authentic meanings for sustainable projects and sustainable wellbeing, as well as the sustainability of relationships, of groups and communities for wellbeing and flourishing, also taking into account connectedness and relationships with nature [11].

The psychology of harmonization [11] could represent a pillar for building a solid psychology of sustainability and sustainable development [26]. This contribution of the psychology of harmonization as a basis for sustainability and sustainable development is introduced for the first time as a promising perspective. Human beings can exist harmoniously with nature even though we have to consume natural resources [4] and it can happen both in geographical and temporal perspectives [11]. Referring to harmonization processes, many elements need to be taken into consideration, going beyond the current natural world and other people close to us, by being sensitive to other people far away in space, as well as the natural world others have left us from the past, the use of resources in the present in relation to the natural world and other people also geographically far from us in the present and the natural world we construct, leave and prepare for others who will come after us and who at present are temporally located in the future [11].

In the relationship to the natural world from the Eastern philosophy both the perspectives of Daoism and Confucianism [4] give us interesting axes of reflections. Daoism emphasizes harmony with the world and Confucianism highlights to harmonize the world. Daoism refers to harmony with the world, avoiding unnecessary damage and harm and maintaining a balance with nature. It asks for an accord between humanity and the natural world accommodating the natural world, highlighting the value of harmony itself. Confucianism underlines harmonize the world, stressing the active role of individuals in the promotion of harmonization generating harmony within the society. Di Fabio $[11,21]$ recollected these precious perspectives introducing the guiding principle of balancing for harmonization with the world and within the world.

This construction in terms of harmonization comes from the past to the present and towards the future, regarding not only individuals but also attending to groups, organizations, society, and the whole world, including relationships with the natural world. Starting from the past and regaining the deep roots permits a new view of the present, building a new awareness to construct a more meaningful and flourishing future using respect, relationality and connectedness in terms of harmonization towards nature, preparing the future for others after us, carefully thinking not only not to waste but mainly to oxygenate and invigorate positive processes and resources including the natural world, on the basis of a generative and harmonic perspective.

The psychology of sustainability and sustainable development call for building preventive strengths and oxygenating processes in a zone of proximal development $[17,64]$. This means having in mind that true sustainable development can only be situated in an area of real progress within the proximal area of the expression of resources, of a person, as well as of a system. This means advancing harmonization requests that do not go beyond real sustainability or generate demands that exceed resources or that are too small and thereby risk a stagnating process that undermines flourishing for the person, as well as for an organization or a community [11].

Processes of reflexivity could help in this direction, considering that reflexivity is defined as a process $[65,66]$ that could be applied for the progress of the person, the community and the whole world. With regard to the distinction between reflection and reflexivity, reflection is thinking back on the past and focusing deep and serious consideration of memories, experiences and cognitions. It is retrospective and brings the past into the present. Reflexivity is a second-order cognitive process of strong evaluation, that entails self-conscious evaluation of alternate ways of acting in the future [65-67]. This process is prospective and connects the present to the future. The dual processes of reflection 
and reflexivity have been conceptualized as "a two stage process" [68] (p. 5). Reflexivity transforms knowledge gained from reflections into new understandings that shape a different perspective from which to envision and build the next chapter. Reflexivity empowers the person/community to go beyond the deep, serious thoughts of reflection in order to move to a new perspective from which to view the transition problem, clarify priorities, and envision a possible future to concretely build on through action. Reflexivity permits the development of a new configuration that is more active than passive. In conclusion, reflexivity offers a useful way to plan the future towards harmonization and a sustainable development.

Putting processes of reflexivity in place to facilitate harmonizing refers to the person, as well as the community [11,21]. More specifically, reflexivity could focus on the following questions: Who I am, Who I am able to become, Who I am comfortable to become, Who I want to become, and the same questions paraphrased for the community, according to the authentic self and process of self-attunement [17] for using intrapersonal and interpersonal talents for flourishing [14,21]. The authentic Self individuates purposes that are most significant for the individual/community in line with the realization of a life of true meaning [24,69]. Self-attunement [17] regards the integration of the objective talents and potential of an individual/community (what I am able to) and the subjective talents and potential (what energizes me, what motivates me to do) in line with a self-construction full of deep meaning for the person as well the community [17] considering processes of harmonization with the world, the world, in the world. Self-attunement permits individuals/community to recognize a confrontation between objectivity and subjectivity, considering the deep value of harmonization in order to gain authentic aims through harmonization, building a sustainable development linked to a deep meaning, balancing different aspects, and flourishing in harmony and constructing wellbeing (Table 4).

Table 4. Psychology of Harmonization as a pillar for Psychology of sustainability and sustainable development.

\begin{tabular}{|c|c|}
\hline Harmony & Sustainability \\
\hline Traditional Perspective & Traditional Perspective \\
\hline \multirow{7}{*}{$\begin{array}{l}\text { Daoism } \\
\text { Harmonize with the world: Avoiding unnecessary damage and harm and maintaining a balance with nature. } \\
\text { Confucianism } \\
\text { Harmonize the world: Active role of individuals in the promotion of harmony and generating harmony within } \\
\text { the society. }\end{array}$} & Avoiding, exploitation, depletion, irreversible alteration \\
\hline & $\begin{array}{l}\text { Small amount of resources, negative vision of stimuli, } \\
\text { damage/threat }\end{array}$ \\
\hline & Abuse, exhaustion, and permanent modification \\
\hline & $\begin{array}{l}\text { Advanced perspective } \\
\text { Psychology of sustainability and sustainable development } \\
{[26,70]}\end{array}$ \\
\hline & Promoting, enrichment/equip, grow, flexible change \\
\hline & $\begin{array}{l}\text { Regenerated and regenerating resources, positive vision } \\
\text { of stimuli, opportunity/challenge }\end{array}$ \\
\hline & Enhancement, development, and flexible transformation \\
\hline \multicolumn{2}{|l|}{$\begin{array}{l}\text { Advanced perspective } \\
\text { Psychology of harmony as harmonic harmonization [11] }\end{array}$} \\
\hline \multicolumn{2}{|l|}{$\begin{array}{l}\text { Psychological process of complex harmonization: Inner self/plural identities, others and contexts included the } \\
\text { natural world, synchronically and diachronically in the space and in the time. }\end{array}$} \\
\hline \multicolumn{2}{|c|}{$\begin{array}{l}\text { - } \quad \text { from the past to the present towards the future; } \\
\text { - } \quad \text { regarding not only individuals but also groups, organizations, society, and the whole world including relationships with the natural world; }\end{array}$} \\
\hline $\begin{array}{l}\text { new awareness to construct a more meaningful and flourishing future using respect, relationality and conr } \\
\text { preparing the future for the others after us carefully thinking to oxygenate and invigorate positive processes } \\
\text { generative and harmonic perspective. }\end{array}$ & $\begin{array}{l}\text { ectedness in terms of harmonization towards nature too, } \\
\text { and resources included the natural world, on the basis of a }\end{array}$ \\
\hline
\end{tabular}

\section{Conclusions}

\subsection{The Positive Preventive Psychology of Harmonization}

A positive preventive perspective underlines the importance of building strengths. The psychology of harmonization [11,21] and the psychology of sustainability and sustainable development $[26,70]$ are promising theoretical frameworks for research and intervention from a preventive perspective. 
Traditionally prevention is articulated in three levels of actions: Primary prevention, secondary prevention, tertiary prevention [71]. Primary prevention is focused on both avoiding the emergence of a problem before it begins and on promoting psychological wellbeing. Secondary prevention regards early interventions when first symptoms emerged. Tertiary prevention aims to decrease symptoms and to support the functional recovery of the individual. In a primary prevention perspective, it is possible to underline that preventive actions are more effective when the efforts to increase the resources are combined with the efforts to decrease the risks $[60,61]$. Primary prevention is thus particularly dedicated to building strengths of individuals with a focus on early interventions that enhance and promote resources and talents of individuals to prevent negative outcomes in the future $[27,58,60,61$, 72,73].

The psychology of harmonization [11,21] emphasizes the importance to act early in a primary prevention perspective, considering the importance to build strengths: from the intrapersonal dimension to enhance interpersonal and community strengths to protect and sustain the environment and the relationships in/with the environment (see Table 5). It asks for intensifying the study of processes that facilitate the realization of harmonization, with attention to parts of the self, with others (internal and external relational contexts), with persons, groups, and community/ies, and with the natural world, taking into account both a synchronic and diachronic dimensions. The psychology of harmonization [62] presents itself as a new pillar able to give valuable contributions to the psychology of sustainability and sustainable development [21,70,74]. The guiding principle of balancing [62] is a promising psychological point of reference to reach harmonization, offering a new promising perspective of psychological research and intervention from a prevention perspective.

The construction of culture-inclusive approaches in psychology [75] are also the basis for a new step forward for harmonization: The psychology of cross-cultural harmony [11,12] balancing too much individualism and too much collectivism starting from primary prevention for a new cross-cultural balancing in terms of universal psychology.

Table 5. Positive Preventive Psychology of Harmonization [11,21].

\begin{tabular}{ll}
\hline \multicolumn{2}{c}{ Positive Preventive Psychology of Harmonization } \\
\hline Early act in a primary prevention perspective & $\begin{array}{l}\text { Importance to build strengths from the intrapersonal } \\
\text { dimension at service of interpersonal dimension and } \\
\text { for the community/ies to build strengths in/for the } \\
\text { environment and the relationships in/with the } \\
\text { environment }\end{array}$ \\
\hline $\begin{array}{l}\text { Intensifying the study of processes that facilitate the } \\
\text { realization of harmonization }\end{array}$ & $\begin{array}{l}\text { with parts of the self, with others (internal and } \\
\text { external relational contexts), person, group, } \\
\text { community/ies (... ) until to the natural world, } \\
\text { taking into account both synchronic and diachronic } \\
\text { dimensions }\end{array}$ \\
\hline
\end{tabular}

guiding principle of balancing for harmonization, offering new promising perspectives of psychological research, and intervention from a prevention perspective for the Psychology of Sustainability and Sustainable Development [14,75].

\subsection{Future Perspectives}

The innovative theoretical perspective regarding the psychology of harmonization represents a promising normative framework to be further analyzed through empirical studies, opening promising perspectives. In particular, it could be important that further empirical studies examined how harmony, if achieved, could contribute to individual and societal wellbeing. It could be also essential to develop specific instruments to measure the degree of harmonization according to the perspective presented in this paper, with attention to parts of the self, with others (internal and external relational contexts), with persons, groups, and community/ies, and with the natural world, taking into account both 
a synchronic and diachronic dimensions. Moreover, it could be also significant to empirically study how the psychological resources introduced as for example intrapreneurial self-capital and acceptance of change can contribute to the harmony of individuals or groups. Possible questions are the following: Does fostering intrapreneurial self-capital really foster harmonization in a group, or can it not rather lead to resentment against the over-zealous intrapreneurs? Is acceptance of change always helpful for achieving harmonization? If a group already lives in harmony, couldn't a too-ready willingness to accept proposed changes disturb that harmony again? All these questions remain still open for further empirical studies. Another issue important to be empirically analyzed is if a sustainable development will be reached by fostering harmonization. It could be also interesting to verify the casual relationships between personal strength (e.g., resilience and empathy) and harmonization processes. In fact, for example, a sustainable economy might conceivably foster societal harmonization, and a harmonious society might foster the development of personal strengths.

Harmonization is a goal that is to be striven for, but many questions remain still open, as for example, harmonization on one level (e.g., the society) can presumably conflict with harmonization on the other levels (e.g., the individual): How are the different harmonization processes harmonized? Also, what exactly does harmonization on each level imply? Furthermore, the general notion of balance is rather vague: Exactly when is balance achieved at different levels? What criteria do we have for deciding this? Is a collectivist society necessarily more harmonious than an individualist society? All these questions are beyond the aims of this paper and remain open for further research.

Author Contributions: A.D.F. and A.T. conceptualized the work and ideated the structure. They analyzed the literature and wrote the manuscript. The authors read and revised the manuscript several times.

Funding: This research received no external funding.

Conflicts of Interest: The authors declare no conflict of interest.

\section{References}

1. Guthrie, W.K.C. A History of Greek Philosophy; Cambridge University Press: Cambridge, UK, 1962; Volume I, ISBN 100521294207.

2. Mandelbrot, B.B. On the geometry of homogeneous turbulence, with stress on the fractal dimension of the iso-surfaces of scalars. J. Fluid Mech. 1975, 72, 401-416. [CrossRef]

3. Chen, S.X. Harmony. In The Encyclopedia of Positive Psychology; Lopez, S.J., Ed.; John Wiley \& Sons: Hoboken, NJ, USA, 2009.

4. Li, C. The Confucian ideal of harmony. Philos. East West 2006, 56, 583-603. [CrossRef]

5. Li, C. The ideal of harmony in ancient Chinese and Greek philosophy. Dao 2008, 7, 81-98. [CrossRef]

6. Leung, K.; Koch, P.T.; Lu, L. A dualistic model of harmony and its implications for conflict management in Asia. Asia Pac. J. Manag. 2002, 19, 201-220. [CrossRef]

7. Sundararajan, L. The Chinese notions of harmony, with special focus on implications for cross-cultural and global psychology. Hum. Psychol. 2013, 41, 25-34. [CrossRef]

8. Ames, R.T.; Rosemont, H., Jr. The Analects of Confucius/A Philosophical Translation; Ballantine: New York, NY, USA, 1998; ISBN 100345434072.

9. Lu, R.R. Zhung-guo gu-dai xiang-dui guan-xi si-wei tan-tao [Investigations of the Idea of Relativity in Ancient China]; Shang Ding Wen Hua: Taipei, Taiwan, 2004.

10. Fung, Y.-L. The Spirit of Chinese Philosophy; Beacon: Boston, MA, USA, 1962; ISBN 13 978-0837128160.

11. Di Fabio, A. Promoting Dignity and Well-Being through Healthy Organizations and Work Environments. Invited lecture in the Roundtable Advancing International Prevention Science-Promoting Empowerment and Global Partnerships. In Proceedings of the 126th Annual American Psychological Association (APA) Convention, San Francisco, CA, USA, 9-12 August 2018.

12. Di Fabio, A. The psychology of positive healthy organizations: The challenges of cross-cultural primary prevention for the construction of individual, contextual, group, community strengths towards harmony and sustainability. Counseling Giornale Italiano di Ricerca e Applicazioni. in press. 
13. Di Fabio, A. Positive Relational Management for healthy organizations: Psychometric properties of a new scale for prevention for workers. Front. Psychol. 2016, 7, 1523. [CrossRef] [PubMed]

14. Di Fabio, A. The Psychology of Positive Healthy Organizations: The Challenges of Cross-Cultural Primary Prevention for the Construction of Individual, Contextual, Group, Community Strengths towards Harmony and Sustainability. In Proceedings of the Ninth International Asian Association of Indigenous and Cultural Psychology (AAICP) Conference "Promoting health, happiness and quality of life: Psychological, social and cultural perspectives", Faculty of Psychology and Education, University of Malaysia Sabah, Koto Kinabalu, Malaysia, 25-27 July 2018.

15. Guichard, J. Self-constructing. J. Voc. Behav. 2009, 75, 251-258. [CrossRef]

16. Guichard, J. Les théories de la construction des parcours professionnels et de la construction de soi: Deux approches de la construction de la vie individuelle. In Proceedings of the Colloque International INETOP, Paris, France, 17-19 March 2010.

17. Di Fabio, A. The new purposeful identitarian awareness for the twenty-first century: Valorize themselves in the Life Construction from youth to adulthood and late adulthood. In The Construction of the Identity in 21st Century: A Festschrift for Jean Guichard; Di Fabio, A., Bernaud, J.-L., Eds.; Nova Science Publishers: New York, NY, USA, 2014; pp. 157-168. ISBN 978-1-63463-218-8.

18. Maree, J.G. Counselling for Career Construction: Connecting Life Themes to Construct Life Portraits. Turning Pain into Hope; Sense: Rotterdam, The Netherlands, 2013; ISBN 9789462092723.

19. Blustein, D.L. A relational theory of working. J. Voc. Behav. 2011, 79, 1-17. [CrossRef]

20. Di Fabio, A. Academic Relational Civility Scale: A multidimensional "mirror" measure. Counseling Giornale Italiano di Ricerca e Applicazioni 2018, 11. [CrossRef]

21. Di Fabio, A. The psychology of harmony as harmonization: New perspectives of balancing as guiding principle. Counseling Giornale Italiano di Ricerca e Applicazioni. in press.

22. Guichard, J. Se faire soi. L'orientation Scolaire et Professionnelle 2004, 33, 499-533. [CrossRef]

23. Guichard, J. Life-long self-construction. Int. J. Educ. Vocat. Guid. 2005, 5, 111-124. [CrossRef]

24. Di Fabio, A.; Blustein, D.L. From meaning of working to meaningful lives: The challenges of expanding decent work. Front. Psychol. 2016, 7, 1119. [CrossRef] [PubMed]

25. Di Fabio, A. Intrapreneurial Self-Capital: A new construct for the 21st century. J. Employ. Couns. 2014, 51, 98-111. [CrossRef]

26. Di Fabio, A. Positive Healthy Organizations: Promoting well-being, meaningfulness, and sustainability in organizations. Front. Psychol. 2017, 8, 1938. [CrossRef] [PubMed]

27. Di Fabio, A.; Kenny, M.E. From decent work to decent lives: Positive Self and Relational Management (PS\&RM) in the twenty-first century. Front. Psychol. 2016, 7, 361. [CrossRef] [PubMed]

28. Judge, T.A.; Erez, A.; Bono, J.E.; Thoresen, C.J. The Core Self-Evaluations Scale: Development of a measure. Pers. Psychol. 2003, 56, 303-331. [CrossRef]

29. Maddi, S.R. Issues and interventions in stress mastery. In Personality and Disease; Friedman, H.S., Ed.; Wiley: New York, NY, USA, 1990; pp. 121-154. ISBN 13 978-0136347279.

30. Tierney, P.; Farmer, S.M. Creative self-efficacy: Its potential antecedents and relationship to creative performance. Acad. Manag. J. 2002, 45, 1137-1148. [CrossRef]

31. Tugade, M.M.; Fredrickson, B.L. Resilient individuals use positive emotions to bounce back from negative emotional experiences. J. Pers. Soc. Psychol. 2004, 86, 320-333. [CrossRef] [PubMed]

32. Midgley, C.; Maehr, M.L.; Hruda, L.Z.; Anderman, E.; Anderman, L.; Freeman, K.E.; Urdan, T. Manual for the Patterns of Adaptive Learning Scales; University of Michigan: Ann Arbor, MI, USA, 2002; Available online: http:/ / www.umich.edu/ \{\}pals/PALS\%202000_V13Word97.pdf (accessed on 30 July 2018).

33. Frost, R.O.; Shows, D.L. The nature and measurement of compulsive indecisiveness. Behav. Res. Ther. 1993, 31, 683-692. [CrossRef]

34. Mann, L.; Burnett, P.; Radford, M.; Ford, S. The Melbourne Decision Making Questionnaire: An instrument for measuring patterns for coping with decisional conflict. J. Behav. Decis. Mak. 1997, 10, 1-19. [CrossRef]

35. Blustein, D.L. The Psychology of Working: A New Perspective for Counseling, Career Development, and Public Policy; Lawrence Erlbaum Associates: Mahwah, NJ, USA, 2006; ISBN 978-0805858792.

36. Di Fabio, A.; Kenny, M.E. Academic Relational Civility as a Key Resource for Sustaining Well-Being. Sustainability 2018, 10, 1914. [CrossRef] 
37. Di Fabio, A.; Gori, A. Assessing Workplace Relational Civility (WRC) with a new multidimensional "mirror" measure. Front. Psychol. 2016, 7, 890. [CrossRef] [PubMed]

38. Peiró, J.M.; Rodríguez, I. Work stress, leadership and organizational health. Papeles del Psicólogo 2008, $29,68-82$.

39. Tetrick, L.E.; Peiró, J.M. Occupational Safety and Health. In The Oxford Handbook of Organizational Psychology; Oxford University Press: Oxford, UK, 2012; Volume 2, ISBN 101598888889.

40. Horiuchi, S.; Tsuda, A.; Aoki, S.; Yoneda, K.; Sawaguchi, Y. Coping as a mediator of the relationship between stress mindset and psychological stress response: A pilot study. Psychol. Res. Behav. Manag. 2018, 11, 47. [CrossRef] [PubMed]

41. Matsuda, T.; Tsuda, A.; Kim, E.; Deng, K. Relationship between decisional balance for stress management behavior and subjective well-being in Japanese, Chinese, and Korean college students: P1754. Int. J. Psychol. 2016, 51, 703.

42. Tanaka, Y.; Tsuda, A. Japanese features of perceiving well-being and its effect on stress. Int. J. Psychol. 2016, 51, 658.

43. Gallagher, A.; Tschudin, V. Educating for ethical leadership. Nurse Educ. Today 2010, 30, 224-227. [CrossRef]

44. Hargreaves, A.; Fink, D. Sustaining leadership. Phi Delta Kappan 2003, 84, 693-700. [CrossRef]

45. Hargreaves, A.; Fink, D. The seven principles of sustainable leadership. Educ. Leadersh. 2004, 61, 8-13.

46. George, B. Mindfulness helps you become a better leader. Harvard Bus. Rev. 2012, 26, $21-32$. Available online: http://gsg.students.mtu.edu/wordpress/wpcontent/uploads/2015/11/MindfulnessHelps-You-Become-a-Better-Leader-article-2.pdf (accessed on 30 July 2018).

47. Herold, I.M.H. The Mindful Library Leader. Lib. Issues Brief. Fac. Adm. 2013, 33, 1-4.

48. Ehrhart, M.G. Leadership and procedural justice climate as antecedents of unit-level organizational citizenship behavior. Pers. Psychol. 2004, 57, 61-94. [CrossRef]

49. Greenleaf, R.K. Servant Leadership: A Journey into the Nature of Legitimate Power and Greatness; Paulist Press: New York, NY, USA, 1977; ISBN 10 080910220X.

50. Di Fabio, A.; Bucci, O. Green positive guidance and green positive life counseling for decent work and decent lives: Some empirical results. Front. Psychol. 2016, 7, 261. [CrossRef] [PubMed]

51. Di Fabio, A.; Kenny, M.E. Connectedness to nature, personality traits and empathy from a sustainability perspective. Curr. Psychol.. in press. [CrossRef]

52. Davis, M.H. A multidimensional approach to individual differences in empathy. JSAS: Cat. Sel. Doc. Psychol. 1980, 10, 85.

53. Mayer, F.S.; Frantz, C.M. The connectedness to nature scale: A measure of individuals' feeling in community with nature. J. Environ. Psychol. 2004, 24, 503-515. [CrossRef]

54. Herbek, T.A.; Yammarino, F.J. Empathy training for hospital staff nurses. Group Organ. Manag. 1990, 15, 279-295. [CrossRef]

55. Hatcher, S.L.; Nadeau, M.S.; Walsh, L.K.; Reynolds, M. The teaching of empathy for high school and college students: Testing Rogerian methods with the Interpersonal Reactivity Index. Adolescence 1994, 29, 961-974.

56. Wündrich, M.; Schwartz, C.; Feige, B.; Lemper, D.; Nissen, C.; Voderholzer, U. Empathy training in medical students-A randomized controlled trial. Med. Teach. 2017, 39, 1096-1098. [CrossRef]

57. Di Fabio, A.; Gori, A. Developing a new instrument for assessing Acceptance of Change. Front. Psychol. Sect. Organ. Psychol. 2016, 7, 802. [CrossRef] [PubMed]

58. Di Fabio, A.; Kenny, M.E. The contributions of emotional intelligence and social support for adaptive career progress among Italian youth. J. Career Dev. 2015, 42, 48-59. [CrossRef]

59. Di Fabio, A.; Kenny, M.E.; Claudius, M. Preventing distress and promoting psychological well-being in uncertain times through career management intervention. In The Cambridge Handbook of International Prevention Science; Israelashvili, M., Romano, J.L., Eds.; Cambridge University Press: Cambridge, UK, 2016; pp. 233-254. ISBN 9781107087972.

60. Hage, S.M.; Romano, J.L.; Conyne, R.K.; Kenny, M.; Matthews, C.; Schwartz, J.P.; Waldo, M. Best practice guidelines on prevention practice, research, training, and social advocacy for psychologists. Couns. Psychol. 2007, 35, 493-566. [CrossRef]

61. Kenny, M.E.; Hage, S.M. The next frontier: Prevention as an instrument of social justice. J. Prim. Prev. 2009, 30, 1-10. [CrossRef] [PubMed] 
62. Di Fabio, A. La Psicologia dell'armonia: Nuove prospettive di balancing [Psychology of harmony: New perspectives of balancing]. Counseling Giornale Italiano di Ricerca e Applicazioni. in press.

63. Brundtland Report. Our Common Future; Butterworth: New York, NY, USA, 1987; ISBN 13 978-0192820808.

64. Vygotsky, L.V. Pensiero e Linguaggio [Thought and Language]; Laterza: Rome, Italy, 1934; ISBN 9788809200630.

65. Savickas, M.L. Reflection and reflexivity during life-design interventions: Comments on Career Construction Counseling. J. Voc. Behav. 2016, 97, 84-89. [CrossRef]

66. Savickas, M.; Guichard, J.; Pouyaud, J.; Bangali, M.; Cohen-Scali, V.; Robinet, M.L.; Santos, G. Research on the Process of Narrative Career Counseling. J. Voc. Behav. 2016, 97, 1-90. [CrossRef]

67. Taylor, B.C. Reminiscences of Los Alamos: Narrative, critical theory, and the organizational subject. West. J. Commun. 1990, 54, 395-419. [CrossRef]

68. Dallos, R.; Stedman, J. Flying over the swampy lowlands: Reflective and reflexive Practice. In Reflective Practice in Psychotherapy and Counselling; Dallos, R., Stedman, J., Eds.; Open University Press: Maidenhead, UK, 2009; pp. 1-22. ISBN 139780335240517.

69. Bernaud, J.-L. Psychologie de L'accompagnement: Concepts et Outils pour Développer le Sens de la vie et du Travail; Dunod: Paris, France, 2015; ISBN 9782100725496.

70. Di Fabio, A. The psychology of sustainability and sustainable development for well-being in organizations. Front. Psychol. 2017, 8, 1534. [CrossRef]

71. Caplan, G. Principles of Preventive Psychiatry; Basic Books: Oxford, UK, 1964; ISBN 100422982709.

72. Di Fabio, A.; Saklofske, D.H. Comparing ability and self-report trait emotional intelligence, fluid intelligence, and personality traits in career decision. Pers. Individ. Differ. 2014, 64, 174-178. [CrossRef]

73. Di Fabio, A.; Saklofske, D.H. Promoting individual resources: The challenge of trait emotional intelligence. Pers. Individ. Differ. 2014, 65, 19-23. [CrossRef]

74. Di Fabio, A.; Tsuda, A. New challenges for a better prevention: Gaining from balancing and positivity. In Positive Psychology for Healthy Organizations: The Challenge of Primary Prevention in a Cross-Cultural Perspective; Di Fabio, A., Ed.; Nova Science Publishers: New York, NY, USA, in press.

75. Hwang, K.K.; Tsuda, A. The construction of culture-inclusive approaches in psychology. Jpn. Psychol. Res. 2016, 58, 1-3. [CrossRef] 